\title{
REVIEW
}

\section{The Major Cause of the Collapse of the Versailles System}

\section{Yiran Jiang*}

Beijing Academy, Beijing, 100000, China

\begin{tabular}{l}
\hline ARTICLE INFO \\
\hline Article history \\
Received: 17 April 2020 \\
Accepted: 17 April 2020 \\
Published Online: 30 June 2020 \\
Keywords: \\
Treaty of Versailles \\
The Versailles system \\
Germany \\
The rise of the Nazi
\end{tabular}

\section{Introduction}

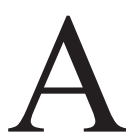
fter World War I, major victors of the war, including but not limited to Britain, French, and the United States, convened Paris Peace Conference at the Palace of Versailles. After a long time of negotiation, on June 28th, 1919, the Entente countries (Britain, French, the United States, etc.) signed the Treaty of Peace between the Allied and Associated Powers and Germany, and Protocol, in short, which is known as Treaty of Versailles. This treaty mainly focused on finalizing punishments for Germany. Following the Treaty of Versailles, many treaties were made to settle various post-war questions. Hence, a brand-new international order was built by the victors, broadly known as the Versailles System. However, the system did not last long. What is the chief cause of the collapse of the Versailles System? This article attempts to address this question.

The short peace between World War I and World War II lasted only about 20 years. When referring to the "peace"

\begin{abstract}
The establishment of the Versailles System was marked with the Paris Peace Conference, which aimed to settle peace for World War I. The peace settlement was an excuse for the allied countries to regain and recover their powers. This, in turn, called for large amount of reparations and punishments on the losing countries. The signing of the Treaty of Versailles heralded the collapse of the volatile system set up afterwards. Countries adopted the policies of appeasement, complied to the race of powers, and abandoned the so-called consensus on "peace". Indeed, the collapse of the Versailles System had many causes. However, the rise of Nazi was its direct trigger. This article will mainly focus on how the Versailles System led to the rise of the Nazi and what the Nazi did to accelerate the fall of the system.
\end{abstract}

that the Versailles system established after World War I, many people cast doubt on the legitimacy and validity of the Treaty of Versailles. In order to explain the collapse, many articles draw attention to the changes in Europe and the world, changes in international positions, and changes in views towards international organizations. As we all know, the direct cause of the collapse is the start of World War II, which was triggered by the Nazi party. This article mainly focuses on why and how the rise of the Nazi led to the collapse of the Versailles system.

\section{Literature Review}

A certain number of studies have been published on the collapse of the Versailles system, explaining the cause of this collapse.

Some argue it is because the European powers adopted the policy of appeasement and gradually kept aloof from German affairs. This provided a "Goldilocks environment" for Germany's expansion and finally led to the col-

*Corresponding Author:

Yiran Jiang,

Beijing Academy, Beijing, 100000, China;

Email: jiangyiran620@126.com 
lapse. This article believes that appeasement is only a direct cause rather than the root cause. This article believes that the rise of the Nazi is the root cause of the collapse, and the article will explain how post-war punishments and domestic social changes propelled the Nazi to challenge the Versailles system.

Some authors believe that it was the absence of the U.S.'s hegemony that led to the collapse. Since Britain's and France's power began to decline after World War I, there are no leading powers that dominated the Versailles system, and the U.S. did not join the system because it had long adopted the "Monroe Doctrine". Without the presence of one-pole hegemony, the system finally collapsed. This point of view seems convincing from first glance; however, it fails to explain why the system dominated by the U.S hasn't disintegrated since World War II.

A lot of articles point out that the Versailles system made incomplete and blurry regulations regarding Germany's punishments and European safety. Therefore, postwar conflicts were hard to settle within the Versailles system. This article will offer supplementary explanations that mainly focus on how the unstable Versailles system provided loopholes to the Nazi, and thereby undermining the system itself.

\section{Arguments}

Treaty of Versailles violated the sovereignty of the defeated countries and thus undermined the maintenance of the newly-established "peace". Throughout history, the disintegration of old orders was usually accompanied by long-lasting social unrest and economic crash.

World War II was the direct symbol of the collapse of the Versailles system. Among all the factors which contributed to World War II, Nazi's expansion was of big portion in stimulating the war. Analyzing how the rise of Nazi contributed to the collapse of the treaty helps us to understand the defects of the system.

Treaty of Versailles imposed severe punishments on Germany: "In the first place it was, in a phrase made familiar by German propaganda, a "dictated peace". It was imposed by the victors on the vanquished, not negotiated by a process of give-and-take between them ${ }^{[1]}$. For territory solely, Germany lost more than 25,000 square miles of territory: "In the west, Germany restored Alsace and Lorraine to France, ceded two tiny fragments of territory at Eupen and Malmedy to Belgium, and renounced her former customs union with Luxembourg. In the south, Germany ceded a small strip of territory to the new state of Czechoslovakia...In the east, Germany ceded to the Principal Allied and Associated Powers, for eventual transfer to Lithuania, the port of Memel and its hinterland ${ }^{[2]}$." The loss in territory badly weakened Germany's economy: the loss of the Saar eroded Germany's industrial power; the loss of West Prussia caused Germany to lose its most fertile farming land. The Treaty also reduced its military to only 100,000 soldiers, banned the use of submarines or aero-planes, and restricted the armed forces to only six battleships. Believed to be responsible for most losses during the war, Germany had to pay over $\$ 800$ billion.

The German economy suffered a heavy blow. Industrial production fell sharply, and the mark was as valuable as waste paper. People's lives were deteriorating because of the faltering economy. Before World War I the German economy had been dependent on three things: overseas commerce and trade, iron and coal, and its transport and tariff system ${ }^{[3]}$. Germany was once the largest factor supplier to Italy and Russia; Britain and France were also its trading partners. However, the treaty of Versailles hindered Germany's trade by imposing commercial restrictions. The Treaty of Versailles also contained terms that did not allow Germany to charge custom duties on imports, denying Germany another large source of income ${ }^{[4]}$. This eliminated Germany's source of income gaining from the tariff system. The territorial losses also caused damage to the German industry. Aforementioned, Germany was highly dependent on iron and coal. The loss of Alsace-Lorraine to France meant the loss of ore-fields for Germany, a major loss given that these ore-fields had contained seventy-five percent of Germany's iron-ore ${ }^{[4]}$.

The severe punishments on Germany led to dissatisfaction: rebellions were inevitable, and people were on strikes. On October 29, 1918, sailors at a naval base near Kiel rebelled and other major naval bases also revolted as the government lost control of the situation. On October 23rd, 1923, the workers led by Telman(a communist activist) organized an uprising in Hamburg. German political structure changed sharply, from an autocracy to a republic, from monarchy to extreme socialism. Under such conditions, citizens wanted a government that could provide sufficient food and a peaceful life. After World War I, people accepted the Weimar Republic because they believed that the government would mediate effectively with the winning countries. However, the compromise made by the government infuriated the people. Radical ideas and German nationalism were stimulated by the dissatisfaction towards life and the broken economy, providing a hotbed for the rise of Adolf Hitler and the Nazi.

In 1919, Hitler set up the Nazi Party, and his supporters grew quickly throughout the years. How did Hitler become popular? He had the skills of a modern politician capable of leading people to hear what they wanted to hear. As Evans writes, "The vagueness of the Nazi program, its symbolic 
mixture of old and new, its eclectic, often inconsistent character, to a large extent allowed people to read into it what they wanted to and edit out anything they might have found disturbing ${ }^{[5]}$." Promising to denounce the Treaty of Versailles and the Weimar Republic was in part of the Nazi propagan$\mathrm{da}$, which soon became broadly welcomed since this promise guaranteed better life and better chances to the people. The national anthem of the Reich, "Deutschland, Deutschland uber Alles" ("Germany, Germany above all else.") drew in the German people who felt that their nation needed help out of the low that the Treaty of Versailles and the end to the Weimar Republic, and these were the main themes in Nazi propaganda ${ }^{[6]}$. Hitler prudently utilized people's resentment towards the Treaty of Versailles and navigated the crowd psychology to gradually gain his popularity.

Treaty of Versailles led to implacable social conflicts and resentments in Germany. The economic destruction, geographic separation, and military restriction aroused German people's craving to restore and unite Germany once again. It was Hitler that determined to accomplish the task of restoration. In 1933, the president Hindenburg made him chancellor. After a series of efforts announcing himself the dictator, he took obvious violations of the Treaty of Versailles. From March 1935, Hitler began to restore German military power. He announced the resumption of military service and the expansion of the German army, including establishing weapons, armored forces and air forces, which were forbidden in the Treaty of Versailles. In March 1936, Hitler announced that Germany would reoccupy and re-militarize the Rhineland zone. Then, Hitler set about solving the territorial problem. In March 1938 Hitler announced the merger of Germany and Austria. In March 1939, Hitler announced the occupation of the rest of Czechoslovakia. In September 1939, Germany flashed on Poland, and World War II broke out.

\section{Conclusion}

To sum up, the expansion of Nazi Germany directly led to the collapse of the Versailles system, and it was the domestic political and social situation that contributed to the rise of the Nazi.

The severe punishments imposed on Germany led to people's dissatisfaction and social unrest, which contributed to the economic crisis and finally to the rise of Nazi. Thanks to the peace settlement, Germany lost a vast majority of land, military forces, and labor forces. What's more, Germany had to pay a large number of penalties to the Entente state. Economic depression and large tax burdens led discontent to spread across Germany. It would be fair to say that Nazi fulfilled German people's demand and found a substitute for their resentment. Nazi agitated the high emotion of people who suffered and held reformation and rebellion which aimed at disrupting the previously-established Versailles system. If there were no unreasonable punishments, Nazi probably wouldn't emerge or gained its popularity; however, history has no going-back.

Fortunately, countries seemed to learn their lessons. For post-World War II peace settlements, countries changed their ways of punishment towards Germany. Even though Germany was divided into four separate parts, each to be governed by one of the Allied Powers. The reparation was reduced and other economic sanctions were also eliminated. The post-war punishments were confirmed by a legal way-through trial. The system built after World War II last longer than the delicate Versailles system.

The significance of the collapse of the Versailles system applies to today's international relationships. The rise of Nazi and the long-lasting conflicts between countries were the unsolved problems after World war I. Even though there are competitions of power existed between countries today, international cooperation is still indispensable. Just like E.H. Carr believed, morality and power are compatible. Building cooperation helps countries eliminate unnecessary suspicions and achieve a multilateral better-off state. Furthermore, appropriate cooperations based on trust reduce operating cost and help countries to gain reputation and acknowledgment in the international society. This requires countries to yield a portion of their rights to exchange certain mutual rights with their cooperative partners. Nevertheless, there's disparity existed between reality and ideality. Based on cooperation, countries also have to consider the disharmony of interests to some extent, for the society people live in nowadays is not the same as that depicted in Kant's culture. In recent years, international society should maintain competitive interactions in international society as well as balancing morality and power.

\section{References}

[1] Edward Hallett Carr. International Relations between the Two World Wars. Houndmills, Basingstoke, Hampshire and London; Macmilian Academic and Professional LTD, 1947: 4.

[2] Edward Hallett Carr. International Relations between the Two World Wars: 6-9.

[3] John Maynard Keynes. The Economic Consequences of Peace. New York: Penguin Books, 1995: 65-66.

[4] John Maynard Keynes. The Economic Consequences of Peace: 87+102-103.

[5] Scott McLemee. The Coming of the Third Reich Newsday Review: 3.

[6] Richard Grunberger. Germany 1918-1945. New York: Harper \& Row, Publishers, Inc., 1964: 99. 